\title{
Influence of Online Learning Behavior and Video Playing Questions on Students' Learning Effect
}

\author{
https://doi.org/10.3991/ijet.v17i02.28535 \\ Zhikai Li \\ Puyang Vocational and Technical College, Puyang, China \\ 10030020@vip.henu.edu.cn
}

\begin{abstract}
The interactive mode in e-learning can effectively stimulate students' learning motivation, especially the way of video questioning as the mainstream interactive mode of e-learning video, which is conducive to improve students' enthusiasm to participate in learning and enhance learning thinking. This study constructs a theoretical model of the impact of E-learning behavior on Students' learning effect, and analyzes the impact of video bullet problem as an intermediary variable on E-learning behavior on students' learning effect. The results show that the overall Cronbach of the questionnaire $\alpha$ the coefficient is 0.883 and Kaiser - Meyer - Olkin value is 0.822 , indicating that the questionnaire has good reliability and validity. The research results of this study provide reference suggestions for exploring the main influencing factors of learning behavior, improving the effect of students' online learning, revealing the optimization strategy of video bullet problem feedback under the network teaching environment, and the production of bullet problem interactive video.
\end{abstract}

Keywords - online learning behavior, video playing question, student, learning effect, mediating effect

\section{Introduction}

To date, with the rapid rise of online education platforms, online learning and ubiquitous learning have become the mainstream forms of e-learning, favored by students, and strongly supported by teachers. As an important form of e-learning, online learning has been concerned by many scholars and has been widely investigated in the field of educational technology. In the context of the rapid development and renewal of information technology, the deep integration of learning methods and information technology has become an inevitable trend. The efficient integration and innovative use of the two have completely changed teachers' teaching behavior and students' learning behavior. Affected by the global epidemic, major online teaching platforms have strengthened integration with traditional offline classroom teaching through massive open online course (MOOCs) and other forms. These platforms have made it extremely convenient for students to study individually and explore in-depth knowledge. Each platform of online learning has developed the functions of learning 
record analysis and learning behavior scenario analysis. Through the background, the traces of online learning behavior of students can be obtained to dig, analyze, and summarize the learning behavior habits of students, which can be fed back to teachers, making teachers pay more attention to the online learning behavior of students in traditional classroom teaching. More online learning platforms have developed the learning situation analysis function to analyze the relationship between students' learning behavior and learning effect with the support of information technologies, such as big data and artificial intelligence, and send the analysis results to the school, so as to facilitate the school to formulate more scientific and reasonable plans during online learning. Thus, the school educational administration department can continuously optimize the curriculum distribution, summarize teaching characteristics, and improve teaching evaluation, so as to make online teaching move toward the direction of scientific, accurate, and personalized education, and realize the high-quality development of education.

Online learning has provided students with abundant learning resources, flexible time arrangement, multidimensional evaluation, and multiscale learning effect analysis. After the online learning is widely used, many students' learning record data will be produced. These data need to be further analyzed and summarized by using information-based teaching methods and fed back to students and teachers. Timely teaching intervention will promote the learning effect of students. Students' learning behavior in the network environment will be recorded in detail, including online time, watching video time, login times, login time, and participation in discussion. We can obtain the learning preferences of individual learners and the laws of learners' group learning behavior through the analysis and statistics of these data. This process provides a favorable support for the scientific and reasonable management of online learners' learning behavior and makes online education more scientific and humanized. The important interactive means is to learn the bullet questions in the video. This method can improve learners' learning experience and learning effect to a certain extent, so that they can review and consolidate their knowledge in time. The interaction in the learning video will enhance learners' understanding of the learning content.

\section{Theoretical basis and research hypothesis}

\subsection{Theoretical basis}

In the relevant research literature of behavioral science theory, Argyris, $\mathrm{C}$ clearly emphasized that the management principle of caring for and respecting people should be adopted in teaching and learning methods, and people's motivation and interest should be stimulated to achieve behavioral goals by meeting people's reasonable needs [1]. The design of teaching platform and the development of online learning resources should focus on the needs of learners and attach importance to learning support services to highlight the dominant position of learners. Effective teaching platform and learning resources can effectively guide and control learners' behavior to a certain extent and support the dynamic analysis of their learning behavior, so as 
to improve the learning effect. We should emphasize the important role of environment on learners' behavior and formulate strategies through learners' feature analysis. Online learning environment will inevitably have a certain effect on learners' learning effect. Teachers should pay attention to optimizing the interactive process between learning environment and learners to establish an effective learning mechanism, adopt strategies in line with learners' cognitive laws, stimulate the generation and maintenance of learners' good learning behavior, and achieve the expected learning output. The online learning process can be regarded as an interactive process between individual learners and between individual learners and groups. A large number of existing studies on behavioral science show that group communication, communication, suggestion, and interpersonal relationship have a great influence on learners' learning effect. This condition indicates that teachers should fully consider the needs of learners' participation in interaction and social interaction when conducting platform course teaching and strengthen interactive friendly design in online learning, so that learners can pay more attention to the learning of knowledge itself and promote the interactive participation among learners. Teachers should pay attention to the role of motivation and reinforcement to promote learners' meaningful learning. Therefore, when designing online courses, we should focus on learners' interests and needs, advocate the design of various resource learning situations and problem task situations to stimulate learners' learning motivation, and strengthen learners' learning through tests or exercises. After learners' goals are achieved, teachers should give learners appropriate rewards in time to encourage them to maintain good learning behavior.

Piaget, $\mathrm{J}$ innovated and developed the constructivist learning theory, emphasizing that the learning situation and teachers' and students' writing are important factors that constitute the learning environment. In a diversified educational and cultural atmosphere [2], learning itself indicates that learners build a knowledge system through their own roles with the help of others (including teachers and classmates, etc.), with the necessary learning resources. In accordance with this theory, the learning process is a process in which a learner actively constructs a knowledge system and acquires knowledge and experience. This process needs constant adjustment and revision, so as to meet the fundamental starting point of the learner and make his knowledge meet the needs. Constructivist learning theory also emphasizes the influence of learners' own learning initiative and the sociality of learning environment on the learning process. Therefore, constructivist learning theory provides significance for the research of online learning behavior. This significance is reflected as follows: online learning should pay attention to the development law of students' learning process and the cultivation and standardization of students' learning behavior. Teachers should focus on guiding students to develop good learning behavior, pay attention to stimulating learners' internal learning motivation, and guide and help them construct their active meaning. Online learning should use the learning environment and technical support of the curriculum platform to provide learners with situations such as autonomous learning and collaborative learning, design resource learning situations and real task and activity situations, and promote learners to actively construct knowledge. Communication and collaboration are the most basic links for learners to 
interact with other learners. In the course implementation, teachers adopt the design and development of collaborative learning activities, and the interactive means between teachers and students is an inevitable channel, which needs to promote each other to achieve the goal of learners' meaning construction.

\subsection{Research hypothesis}

Learning effect refers to the qualitative changes in cognition, technology, and skills caused by learners after learning knowledge or completing learning tasks. Theoretically, the effect of online learning is affected by various aspects, including individual learners (internal factors, such as learner characteristics, psychological factors, knowledge base, and information literacy) and curriculum design (external factors, such as learning environment support, resource design, supervision, and evaluation mechanism). External factors are usually fixed or designed in advance for learners because online learning is a web-based, highly autonomous, and learner-centered learning method, and learner-centered factors are the main factors that affect the online learning effect.

The concept of online learning engagement is an extension of the more mature concept of "work engagement." Rich, B. L proposed that work engagement is a concept of multidimensional evaluation, which refers to all individual investment in specific work, including time [3], energy, intelligence, and other factors. It is an important concept to analyze the relationship between individual and organizational performance. Schaufeli, W described the characteristics, definition, and classification of work input. Bakker [4], A. B discussed the concept of work engagement [5]. The results show that dedicated employees can maintain their engagement by continuously increasing work engagement. On the basis of the concept of work input, learning input has been widely studied with the in-depth research of teaching science. Hu, P.J.H. conducted an empirical test through the experiment of 212 students learning Adobe Photoshop. The experimental data show that the effect of technology-mediated learning is mainly achieved through learning input [6]. Jung, Y used SEM to analyze the relationship among students' self-efficacy, learning engagement, and learning effect in MOOC learning process [7]. The research results show that learning engagement is an important factor affecting students' self-efficacy and learning effect. $\mathrm{Lu}, \mathrm{J}$ analyzed the influence of social interaction among undergraduates in Hong Kong on their learning engagement [8]. The results show that learning engagement can support the improvement of learning effect under the background of effective use of social networking platform. Buelow, J. R research shows that students' online discussion and interactive homework can increase the possibility of learning engagement [9]. Ke, $\mathrm{F}$ believed that the game learning process can activate and maintain learning investment [10]. Halliday, S. E considered that learning engagement is the key factor of academic achievement. The results show that a close relationship is found between children's learning engagement and their preschool skill mastery of mathematics and literacy [11]. The results of Chen, I. S show that a highly positive correlation is found between learning engagement and learning achievement [12]. Therefore, students' online learning investment is the comprehensive performance of 
students' energy investment, emotional investment, and cognitive results in the whole process of online learning. Therefore, hypothesis $\mathrm{H} 1$ is proposed in this study.

H1: Online learning investment positively affects students' online learning behavior.

A large number of studies have shown that the sense of online learning efficacy can directly affect the online learning effect of students, especially the students with strong learning motivation. The stronger the sense of learning efficacy, the more scientific online learning behavior can be formed. Matsui, $\mathrm{T}$ believed that self-efficacy is mainly manifested in performance achievement, modeling, verbal persuasion, and emotional arousal [13]. The results of stepwise regression analysis show that the above four efficacy information sources have a unique contribution to mathematical self-efficacy. Alqurashi, E discussed the relationship between self-efficacy and elearning environment and reviewed the relevant research results of self-efficacy in elearning environment from 1997 to 2015 [14]. Wang, Y research shows that a causal relationship is found between self-efficacy and learning results, and self-efficacy can indirectly and positively predict learning results [15]. The research results of Liu, C.C. show that self-efficacy in learning activities under Web2.0 mode has obvious influence on learning effect [16]. Schunk, D. H thought that students' self-efficacy can promote them to achieve their goals [17]. The research results show that when students feel capable of improving their skills; goal achievement, coupled with high self-efficacy, they are guided to set new and challenging goals. A study by Demirören, $M$ shows that a close relationship is found between the use of self-regulated learning skills and self-efficacy beliefs of medical students [18]. Shea, P studied the relationship between self-efficacy and learning quality scores of 3165 students using online courses. The results show that self-efficacy plays a positive role in improving the learning effect of online learners [19]. Rafiola, $\mathrm{R}$ believed that in the process of industrial revolution 4.0, self-efficacy has a significant effect on students' achievement. The results show that learning motivation [20], self-efficacy, and blended learning have a significant effect on senior high school students' learning achievement. This study proposes hypothesis $\mathrm{H} 2$.

$\mathrm{H} 2$ : Online learning efficacy positively affects the online learning behavior of students.

The concept of learning motivation is derived from the concept of "motivation," which is widely used in psychology. The in-depth study of learning motivation focuses on the applied study of cognitivism. After introducing the concept of motivation into the field of education, learning motivation refers to an individual's internal psychological state when he or she conducts learning behavior, which can effectively measure the original driving factors of his or her learning motivation. However, the measurement of learning motivation is multidimensional and nonlinear, which has aroused extensive research. Schiefele, U conducted high-quality research on this topic. The results show that learning motivation has a significant effect on the quality of understanding and learning experience similar to this paper [21]. Harlen, W systematically reviewed the research on the influence of students' learning motivation [22]. The results show that learning motivation is affected by factors, such as self-esteem, self-efficacy, effort, self-regulation, control point, and goal orientation. Lin, M. H 
selected 116 students from four classes as the research objects and conducted a comparative experiment. The results show that compared with traditional teaching [23], digital learning has a better positive effect on learning motivation. The research of Liu, O. L shows that learning motivation significantly affects the test scores of senior high school students [24]. The results of Liu, T. Y show that adding ubiquitous games in English learning can help students obtain better learning results and motivation, and motivation has an obvious positive relationship with learning results [25]. Tella, A explored the influence of learning motivation on middle school students' mathematics academic achievement [26]. The results show that when learning motivation was used as an interest variable in mathematics academic achievement, significant differences are found in their motivation. The research results of Rahardjanto, A show that learning motivation plays an obvious role in improving students' creative thinking ability and academic performance. This study proposed hypothesis H3 [27].

H3: Online learning motivation positively affects students' online learning behavior.

Behavioral science theory holds that human behavior is generated by motivation and a series of activities to achieve demand goals. Under the background of the highly integrated development of the Internet and modern educational technology, online learning has become an indispensable part of many learning methods of students. Online learning behavior has become a link that students must pay attention to online learning, and its online learning effect has become the focus of attention. Analyzing the relationship between students' online learning behavior and learning effect will help to further adjust online learning strategies. Firmstone, V.R. found that adopting multimethod and multistage learning methods can significantly improve the educational effect of dentists [28]. Magena, S.M. analyzed the types of relationships between students' learning behaviors and academic achievements in theoretical and practical activities [29]. The results show that a significant correlation is found between academic achievement and learning behavior. The research results of Young, M.R. show that supportive classroom behavior can improve students' self-reporting performance and curriculum achievement [30]. Henderson, D analyzed the relationship between students' learning behavior and learning performance results [31]. The results show that students' perception of learning environment affects their skill results. Lu, $\mathrm{H}$ focused on the relationship between learning styles and learning outcomes [32]. The results show that different learning styles have a significant effect on learning outcomes (reading time and discussion time). This study proposes hypothesis $\mathrm{H} 4$.

H4: Online learning behavior positively affects the online learning effect of students.

With the deepening of online learning methods, traditional static online teaching methods cannot improve learners' learning methods. With the gradual emphasis on information technology, users' learning experience and the learning effect can be enhanced by adding interactive functions, such as video quiz, in the process of online learning. The bullet question indicates that the test questions embedded in the learning video pop up at an appropriate time, and the learner completes the answer, making the learning video interactive. Interaction in learning videos can help learners consolidate 
their learning effects and promote positive knowledge construction, thereby gradually approaching teaching objectives. The results of PI, Z show that learners who watch traditional video lectures show higher mobility than learners who watch video lectures containing other people's information [33]. Liu, G. f research shows that video shot in advertising has a positive effect on consumers' health and purchase intention [34]. Wan, A discussed the theoretical and practical importance of barrage technology [35]. Scagnoli, N. I research results show that students' satisfaction with virtual learning is closely related to their perception of video learning [36]. Therefore, this study believes that the application of video-playing-questions as a new educational method can especially satisfy the students' pursuit of novel technology in the online learning process, can make them improve their traditional learning behavior, and make their learning behavior more significantly affect their learning effect. This study proposes hypothesis $\mathrm{H} 5$.

H5: A mediating effect is found in the positive effect of online learning behavior on students' online learning effect.

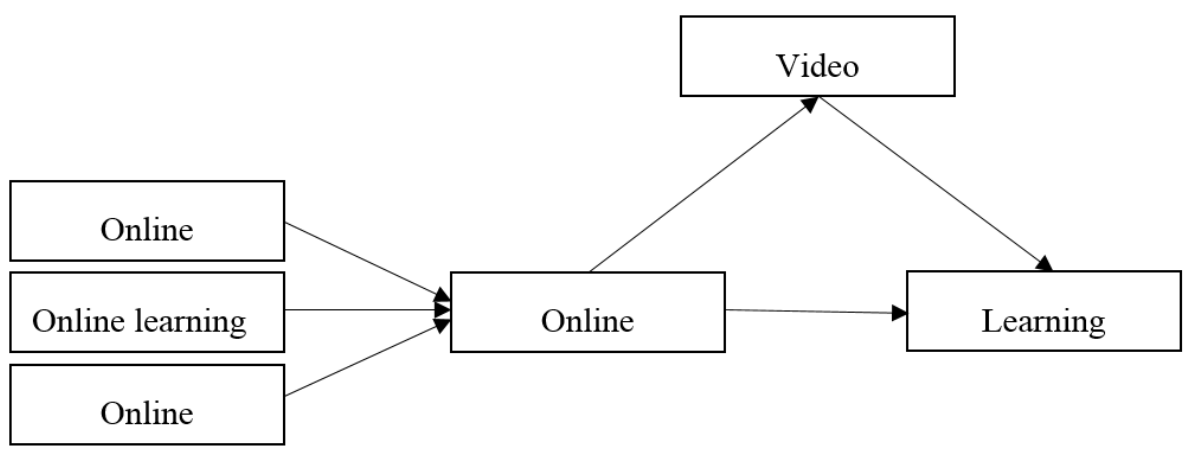

Fig. 1. Research framework of this study

\section{$3 \quad$ Research design}

\subsection{Research object}

Considering that online learning needs to have a good information foundation, this study selects one of the smart campus demonstration schools in Jiangsu Province in 2020 to conduct a questionnaire survey. The questionnaire QR code is generated by means of network questionnaire and submitted to the information management center of the university for distribution throughout the university. In this questionnaire survey, 214 questionnaires were collected through the questionnaire star platform within the specified one day. After excluding the wireless questionnaires, such as incomplete answers to basic information and consistent answers to all questions, 164 valid questionnaires were obtained, with an effective rate of $76.64 \%$. Among the valid respondents, from the gender perspective, 76 males, accounting for $46.34 \%$, and 88 females, accounting for $53.66 \%$, are found. In accordance with grades, 41 freshmen, account- 
ing for $25.00 \%, 67$ sophomores, accounting for $40.85 \%, 47$ juniors, accounting for $28.66 \%$, and 9 seniors, accounting for $5.49 \%$, are found. From the perspective of disciplines, 41 liberal arts students, accounting for $25.00 \%, 67$ science students, accounting for $40.85 \%$, and 56 engineering students, accounting for $34.15 \%$, are found. From the number of online learning platforms, 67 people use one platform, accounting for $40.85 \%, 86$ people use one or three platforms, accounting for $52.44 \%$, and 11 people use more than three platforms, accounting for $6.71 \%$. On the whole, the gender, gender, grade, discipline, and the number of online platforms used by the respondents are fairly balanced, which is representative of the respondents.

\subsection{Research tool}

On the basis of a large number of references to the influence of online learning investment, online learning efficacy and online learning motivation on online learning behavior, and the influence of online learning behavior on learning effect, this study compiles the "questionnaire on the influencing factors of students" online learning effect." The questionnaire is divided into "basic information of learners" (a total of 4 items, including gender, grade, discipline, and the number of online platforms used) and "investigation on influencing factors of online learning effect" (20 items), with a total of 24 items. Among them, 3 questions for online learning, 4 questions for online learning efficacy, 2 questions for online learning motivation, 2 questions for online learning methods, 5 questions for online learning effect, and 4 questions for video playing are found. Each item is designed by (Likert) 5 points to ensure the reliability and validity of the model.

In this study, item analysis and factor correlation test were conducted on all the items in the questionnaire, and internal consistency $\alpha$ coefficient was used to test the homogeneity of the items.

\section{$4 \quad$ Result analysis}

\subsection{Reliability and validity analysis}

The purpose of reliability analysis is to test whether different samples have good reliability (i.e., the stability of data samples). The evaluation of Cronbach's alpha $\alpha$ is the consistency between the scores of each item in the scale, which belongs to the internal consistency coefficient. This method is applicable to the reliability analysis of attitude and opinion questionnaire, as shown in Table 1.

Table 1. Reliability analysis of attitude and opinion questionnaire

\begin{tabular}{|l|c|c|c|c|}
\hline \multicolumn{1}{|c|}{ Variable } & $\begin{array}{c}\text { Issue } \\
\text { number }\end{array}$ & $\begin{array}{c}\text { Total correlation of correc- } \\
\text { tion items (CITC) }\end{array}$ & $\begin{array}{c}\text { Cronbach } \\
\boldsymbol{\alpha} \text { coefficient }\end{array}$ & $\begin{array}{c}\text { Cronbach } \\
\boldsymbol{\alpha} \text { coefficient }\end{array}$ \\
\hline \multirow{2}{*}{$\begin{array}{l}\text { Online learning investment } \\
\text { (Factor1) }\end{array}$} & $\mathrm{A} 1$ & 0.620 & \multirow{2}{*}{0.727} & \multirow{2}{*}{0.883} \\
\cline { 2 - 3 } & $\mathrm{A} 2$ & 0.581 & & \\
\cline { 2 - 3 } & $\mathrm{A} 3$ & 0.458 & \\
\hline
\end{tabular}




\begin{tabular}{|c|c|c|c|}
\hline \multirow{4}{*}{$\begin{array}{l}\text { Online learning efficacy } \\
\text { (Factor2) }\end{array}$} & B1 & 0.652 & \multirow{4}{*}{0.834} \\
\hline & B2 & 0.772 & \\
\hline & B3 & 0.694 & \\
\hline & B4 & 0.547 & \\
\hline \multirow{2}{*}{$\begin{array}{l}\text { Online learning motivation } \\
\text { (Factor3) }\end{array}$} & $\mathrm{C} 1$ & 0.585 & \multirow{2}{*}{0.738} \\
\hline & $\mathrm{C} 2$ & 0.585 & \\
\hline \multirow{2}{*}{$\begin{array}{l}\text { Online learning method } \\
\text { (Factor4) }\end{array}$} & D1 & 0.476 & \multirow{2}{*}{0.644} \\
\hline & D2 & 0.476 & \\
\hline \multirow{4}{*}{$\begin{array}{l}\text { Video bullet question (Fac- } \\
\text { tor5) }\end{array}$} & E1 & 0.434 & \multirow{4}{*}{0.733} \\
\hline & E2 & 0.470 & \\
\hline & E3 & 0.638 & \\
\hline & E4 & 0.560 & \\
\hline \multirow{5}{*}{$\begin{array}{l}\text { Online learning effect } \\
\text { (Factor6) }\end{array}$} & $\mathrm{F} 1$ & 0.544 & \multirow{5}{*}{0.785} \\
\hline & $\mathrm{F} 2$ & 0.649 & \\
\hline & F3 & 0.644 & \\
\hline & $\mathrm{F} 4$ & 0.594 & \\
\hline & F5 & 0.387 & \\
\hline
\end{tabular}

As shown in Table 1, the overall Cronbach $\alpha$ coefficient of the questionnaire is 0.883 , which is greater than 0.8 , indicating that the reliability quality of the research data is high. The minimum value of Cronbach $\alpha$ coefficient for six variable problems is greater than 0.6 , indicating that the reliability is acceptable.

The validity analysis is conducted, as shown in Table 2 .

Table 2. Results of validity analysis

\begin{tabular}{|c|c|c|c|c|c|c|c|}
\hline \multirow[b]{2}{*}{ Name } & \multicolumn{6}{|c|}{ Factor load factor } & \multirow{2}{*}{$\begin{array}{c}\text { Common degree } \\
\text { (common factor } \\
\text { variance) }\end{array}$} \\
\hline & $\begin{array}{c}\text { Factor } \\
1\end{array}$ & $\begin{array}{c}\text { Factor } \\
2\end{array}$ & $\begin{array}{c}\text { Factor } \\
3\end{array}$ & $\begin{array}{c}\text { Factor } \\
4\end{array}$ & $\begin{array}{c}\text { Factor } \\
5\end{array}$ & $\begin{array}{c}\text { Factor } \\
6\end{array}$ & \\
\hline A1 & 0.164 & 0.068 & 0.106 & 0.812 & 0.281 & 0.076 & 0.786 \\
\hline $\mathrm{A} 2$ & 0.048 & 0.236 & 0.147 & 0.783 & 0.035 & -0.008 & 0.694 \\
\hline A3 & 0.434 & 0.079 & 0.165 & 0.525 & 0.000 & 0.0710 & 0.503 \\
\hline B1 & 0.434 & 0.010 & 0.661 & 0.184 & 0.047 & -0.338 & 0.775 \\
\hline B2 & 0.392 & 0.136 & 0.789 & 0.026 & -0.06 & -0.027 & 0.801 \\
\hline B3 & 0.310 & 0.104 & 0.760 & 0.108 & -0.033 & 0.120 & 0.711 \\
\hline B4 & 0.005 & 0.244 & 0.694 & 0.305 & 0.174 & 0.270 & 0.738 \\
\hline $\mathrm{C} 1$ & 0.671 & -0.077 & 0.234 & 0.096 & 0.206 & 0.235 & 0.618 \\
\hline $\mathrm{C} 2$ & 0.789 & 0.070 & 0.153 & 0.127 & -0.017 & 0.112 & 0.68 \\
\hline D1 & -0.071 & 0.243 & 0.124 & 0.287 & 0.730 & 0.101 & 0.706 \\
\hline D2 & 0.159 & 0.040 & -0.065 & 0.022 & 0.854 & -0.202 & 0.802 \\
\hline E1 & 0.444 & 0.016 & 0.357 & 0.226 & -0.235 & 0.557 & 0.741 \\
\hline E2 & 0.484 & 0.260 & 0.094 & 0.456 & 0.090 & -0.145 & 0.548 \\
\hline E3 & 0.691 & 0.134 & 0.173 & 0.229 & 0.013 & -0.02 & 0.578 \\
\hline $\mathrm{E} 4$ & 0.777 & 0.180 & 0.184 & -0.037 & 0.069 & -0.111 & 0.689 \\
\hline
\end{tabular}




\begin{tabular}{|c|c|c|c|c|c|c|c|}
\hline $\mathrm{F} 1$ & 0.162 & 0.672 & 0.155 & 0.208 & 0.054 & -0.394 & 0.703 \\
\hline $\mathrm{F} 2$ & -0.002 & 0.837 & 0.250 & 0.050 & 0.077 & -0.015 & 0.772 \\
\hline F3 & 0.133 & 0.795 & -0.002 & 0.193 & 0.044 & 0.045 & 0.690 \\
\hline $\mathrm{F} 4$ & 0.197 & 0.623 & 0.134 & 0.054 & 0.425 & 0.309 & 0.723 \\
\hline F5 & 0.103 & 0.418 & -0.279 & 0.313 & 0.361 & 0.184 & 0.526 \\
\hline Eigenvalue (before rotation) & 6.395 & 2.655 & 1.484 & 1.259 & 1.104 & 0.889 & - \\
\hline $\begin{array}{l}\text { Variance interpretation rate } \% \\
\text { (before rotation) }\end{array}$ & $\begin{array}{c}31.976 \\
\%\end{array}$ & $\begin{array}{c}13.275 \\
\%\end{array}$ & $7.419 \%$ & $6.294 \%$ & $5.522 \%$ & $4.445 \%$ & - \\
\hline $\begin{array}{l}\text { Cumulative variance interpretation } \\
\text { rate\% (before rotation) }\end{array}$ & $\begin{array}{c}31.976 \\
\% \\
\end{array}$ & $\begin{array}{c}45.251 \\
\% \\
\end{array}$ & $\begin{array}{c}52.670 \\
\% \\
\end{array}$ & $\begin{array}{c}58.963 \\
\%\end{array}$ & $\begin{array}{c}64.486 \\
\% \\
\end{array}$ & $\begin{array}{c}68.931 \\
\% \\
\end{array}$ & - \\
\hline Eigenvalue (after rotation) & 3.366 & 2.693 & 2.66 & 2.292 & 1.813 & 0.963 & - \\
\hline $\begin{array}{l}\text { Variance interpretation rate } \% \text { (after } \\
\text { rotation) }\end{array}$ & $\begin{array}{c}16.830 \\
\%\end{array}$ & $\begin{array}{c}13.463 \\
\%\end{array}$ & $\begin{array}{c}13.299 \\
\%\end{array}$ & $\begin{array}{c}11.458 \\
\%\end{array}$ & $9.067 \%$ & $4.814 \%$ & - \\
\hline $\begin{array}{l}\text { Cumulative variance interpretation } \\
\text { rate\% (after rotation) }\end{array}$ & $\begin{array}{c}16.830 \\
\% \\
\end{array}$ & $\begin{array}{c}30.293 \\
\%\end{array}$ & $\begin{array}{c}43.592 \\
\% \\
\end{array}$ & $\begin{array}{c}55.050 \\
\%\end{array}$ & $\begin{array}{c}64.117 \\
\%\end{array}$ & $\begin{array}{c}68.931 \\
\%\end{array}$ & - \\
\hline Kmo value & \multicolumn{6}{|c|}{0.822} & - \\
\hline Bart spherical value & \multicolumn{6}{|c|}{1453.661} & - \\
\hline Df & \multicolumn{6}{|c|}{190} & - \\
\hline $\mathrm{P}$ value & \multicolumn{6}{|c|}{0} & - \\
\hline
\end{tabular}

The following conditions are shown in Table 2.

The variance interpretation rates of the six factors are $16.830 \%, 13.463 \%$, $13.299 \%, 11.458 \%, 9.067 \%$, and $4.814 \%$. The cumulative variance interpretation rate after rotation is $68.931 \%>50 \%$. This finding indicates that the amount of information of the research item can be extracted effectively. The validity was verified by Kaiser-Meyer-Olkin (KMO) and Bartlett tests. The KMO value is 0.822 , which is greater than 0.8 . The research data information is extremely suitable for extracting information.

In accordance with the analysis of discriminant validity, the square root of AVE of factor1 to factor6 is greater than the maximum of the absolute value of the correlation coefficient between factors, indicating that they have good discriminant validity. The validity and reliability of the questionnaire have extremely good results.

Table 3. Discriminant validity

\begin{tabular}{|l|c|c|c|c|c|c|}
\hline & Factor1 & Factor2 & Factor3 & Factor4 & Factor5 & Factor6 \\
\hline Factor1 & 0.707 & - & - & - & - & - \\
\hline Factor2 & 0.423 & 0.766 & - & - & - & - \\
\hline Factor3 & 0.390 & 0.504 & 0.770 & - & - & - \\
\hline Factor4 & 0.316 & 0.114 & 0.148 & 0.737 & - & - \\
\hline Factor5 & 0.494 & 0.600 & 0.640 & 0.137 & 0.649 & - \\
\hline Factor6 & 0.440 & 0.314 & 0.211 & 0.413 & 0.369 & 0.665 \\
\hline
\end{tabular}

Note: diagonal numbers are the square root value of AVE 


\subsection{Hypothesis test}

SPSS 22.0 software was used to perform regression analysis on the relationship between the related variables of assumptions 1-4, as shown in Table 4.

Table 4. Regression analysis results

\begin{tabular}{|l|l|c|c|c|c|c|}
\hline \multicolumn{1}{|c|}{$\mathbf{X}$} & $\rightarrow$ & $\mathbf{Y}$ & Non standardized regression coefficient & $\mathbf{S E}$ & $\mathbf{Z}$ (CR value) & $\mathbf{p}$ \\
\hline Factor1 & $\rightarrow$ & Factor4 & 0.111 & 0.046 & 2.381 & 0.017 \\
\hline Factor1 & $\rightarrow$ & Factor4 & 0.078 & 0.041 & 1.891 & 0.059 \\
\hline Factor1 & $\rightarrow$ & Factor4 & 0.206 & 0.078 & 2.626 & 0.009 \\
\hline Factor4 & $\rightarrow$ & Factor6 & 2.091 & 0.711 & 2.942 & 0.003 \\
\hline
\end{tabular}

The following conditions are shown in Table 4.

Hypothesis 1 holds. Specifically, online learning investment positively affects the online learning behavior of students. Online learning is to break through the constraints of time and space and let students reconstruct their knowledge. This learning process requires students to invest considerable time and energy, so as to ensure them to form good learning behaviors. However, students should have more learning investment in the future, especially compared with the traditional classroom, online learning lacks real-time on-site supervision of teachers, and students need to maintain high learning investment. Students can effectively improve their learning behavior after ensuring more learning investment.

Hypothesis 2 holds. Online learning efficacy positively affects students' online learning behavior. A large number of research documents have shown that students' self-efficacy affects their learning behavior, and students' self-efficacy is an important factor affecting learners' online learning behavior in the process of online learning. Students' sense of self-efficacy will make them have more initiative and control, improve learners' satisfaction, promote learners' positive learning activities, and produce good learning behavior.

Hypothesis 3 holds. Online learning motivation positively affects students' online learning behavior. The greatest advantage of online learning is that it meets learners' different learning needs and is conducive to stimulating their interest in learning. Strengthening the repetitiveness of knowledge helps learners to have a deep understanding, increases their confidence in learning, transforms external motivation into internal motivation, and stimulates the enthusiasm of online learning, thereby promoting the occurrence of meaningful learning. Therefore, in the process of online learning, the effective stimulation of students' learning motivation is the main consideration to ensure their learning behavior.

Hypothesis 4 holds. Online learning behavior has a positive effect on students' online learning effect. At present, when students study online, their learning behavior is to systematically master relevant knowledge. If students have sufficient learning motivation, learning efficacy, and learning investment, then they can adhere to and complete the whole online learning process, which is conducive to the realization of the real value of online courses. The learning behavior of students strengthens their acquisition of knowledge. The online course selection is diverse, which can fully meet 
the diversified and personalized knowledge learning needs of students, promote them to learn more actively, be full of sufficient enthusiasm for online learning, and form an effective and good learning behavior in the growth period. The high-quality learning resources on the network are deeply integrated through online learning, and students can obtain the benefits brought by the full contribution of online resources, making the learning effect of students more obvious.

Hypothesis $\mathrm{H} 5$ is tested through intermediary effect analysis.

As shown in Tables 5 and 6, H5 is assumed to hold. A complete mediating effect is found in the online learning behavior that positively affects the online learning effect of students. A large number of studies agree that the interactive friendliness of online learning can effectively improve the learning effect. As an important technical means in the process of video learning, video quiz can make rich interactive means, such as selection and filling, and has a high degree of control over the interaction, so that students can maintain a high degree of learning input, enhance their learning efficacy, and stimulate their internal motivation during online learning. For example, video playing questions can directly jump to the position of knowledge points, which improves learners' learning autonomy, enriches interaction design, provides more choices for learners to control their learning behavior, and helps to improve their sense of learning participation, environmental grasp and behavior control, so as to stimulate learning interest and use feedback content for reflection and cognition. Playing the questions in the learning video can enable them to review and consolidate their knowledge in time and improve learners' learning experience and learning effect to a certain extent.

Table 5. Test of mediating effect model

\begin{tabular}{|l|c|c|c|}
\hline & Factor6 & Factor5 & Factor6 \\
\hline Constant & $2.830^{* *}(10.728)$ & $3.068^{* *}(13.891)$ & $2.249^{* *}(5.815)$ \\
\hline Factor4 & $0.150(1.826)$ & $0.193^{* *}(2.816)$ & $0.113(1.360)$ \\
\hline Factor5 & - & - & $0.189^{*}(2.038)$ \\
\hline Sample size & 164 & 164 & 164 \\
\hline $\mathrm{R}^{2}$ & 0.02 & 0.047 & 0.045 \\
\hline Adjust $\mathrm{R}^{2}$ & 0.014 & 0.041 & 0.033 \\
\hline F value & $(1,162)=3.333, \mathrm{p}=0.070$ & $(1,162)=7.928, \mathrm{p}=0.005$ & $(2,161)=3.776, \mathrm{p}=0.025$ \\
\hline
\end{tabular}

${ }^{*} \mathrm{P}<0.05{ }^{* *} \mathrm{P}<0.01$ the value of $\mathrm{T}$ in brackets

Table 6. Summary of mediating effect quantity results

\begin{tabular}{|l|c|c|c|c|c|c|c|c|c|c|}
\hline Term & $\begin{array}{c}\mathbf{C} \\
\text { total } \\
\text { effect }\end{array}$ & $\mathbf{A}$ & $\mathbf{B}$ & $\begin{array}{c}\mathbf{A}^{*} \mathbf{b} \text { interme- } \\
\text { diary effect } \\
\text { value }\end{array}$ & $\begin{array}{c}\mathbf{A}^{*} \mathbf{b} \\
(\mathbf{B o o t} \\
\mathbf{S E})\end{array}$ & $\begin{array}{c}\mathbf{A}^{*} \mathbf{b}(\mathbf{z} \\
\mathbf{v a l u e})\end{array}$ & $\begin{array}{c}\mathbf{A}^{*} \mathbf{b}(\mathbf{p} \\
\text { value })\end{array}$ & $\begin{array}{c}\mathbf{A}^{*} \mathbf{b}(\mathbf{9 5 \%} \\
\mathbf{B o o t C I})\end{array}$ & $\begin{array}{c}\mathbf{C} \\
\text { direct } \\
\text { effect }\end{array}$ & $\begin{array}{c}\text { Test } \\
\mathbf{c o n c l u} \\
\text { sion }\end{array}$ \\
\hline $\begin{array}{l}\text { Fac- } \\
\text { tor4=>Fac } \\
\text { tor5=>Fac } \\
\text { tor6 }\end{array}$ & 0.15 & $0.193^{* *}$ & $0.189^{*}$ & 0.037 & 0.002 & 17.698 & 0 & $\begin{array}{c}-0.002 \sim \\
0.099\end{array}$ & 0.113 & $\begin{array}{c}\text { Complete } \\
\text { mediation }\end{array}$ \\
\hline
\end{tabular}

${ }^{*} \mathrm{P}<0.05^{* *}$ Indicates $\mathrm{P}<0.01$ 


\section{Conclusion}

With the increasingly mature education information technology, online learning has become the main channel for students to develop their career and form lifelong learning habits. The online learning platform addresses the time and space constraints, meets the personalized needs of students, helps students develop good online learning behavior, and comprehensively and efficiently improves their learning effect. This study constructs a theoretical model of the effect of online learning behavior on students' learning effect and analyzes the effect of video playing as an intermediary variable on online learning behavior on students' learning effect. The results show that the Cronbach $\alpha$ coefficient and KMO value of the questionnaire constructed in this study are 0.883 and 0.822 , respectively. The reliability and validity of this questionnaire are good. Online learning input, online learning efficacy, and online learning motivation all have significant positive effects on the online learning behavior of students. A complete mediating effect is found in the online learning behavior that positively affects the online learning effect of students. In the future, we can continue to conduct in-depth research on enriching the influencing factors of online learning behavior, exploring the influence of the content and form of feedback on the learning effect, and mobilizing and maintaining the effective methods of students' online learning effect.

\section{Acknowledgements}

This work was supported by the 2020 guiding plan project of key scientific research projects of colleges and universities in Henan Province China under grant no. 20B880027.

\section{$7 \quad$ References}

[1] Argyris, C. Intervention Theory \& Method: A Behavioral Science View, 1970.

[2] Piaget, J. Piaget's theory. In Piaget and his school. Springer, Berlin, Heidelberg, 1976, pp. 11-23. https://doi.org/10.1007/978-3-642-46323-5_2

[3] Rich, B. L., Lepine, J. A., \& Crawford, E. R. Job engagement: Antecedents and effects on job performance. Academy of management journal, 2010, vol. 53(3), pp. 617-635. https://doi.org/10.5465/amj.2010.51468988

[4] Schaufeli, W., \& Salanova, M. Work engagement. Managing social and ethical issues in organizations, 2007, 135, pp. 177.

[5] Bakker, A. B., Albrecht, S. L., \& Leiter, M. P. Key questions regarding work engagement. European journal of work and organizational psychology, 2011, vol. 20(1), pp. 4-28. https://doi.org/10.1080/1359432x.2010.485352

[6] Hu, P. J. H., \& Hui, W. Examining the role of learning engagement in technologymediated learning and its effects on learning effectiveness and satisfaction. Decision support systems, 2012, vol. 53(4), pp. 782-792. https://doi.org/10.1016/j.dss.2012.05.014 
[7] Jung, Y., \& Lee, J. Learning engagement and persistence in massive open online courses (MOOCS). Computers \& Education, 2018, 122, pp. 9-22. https://doi.org/10.1016/ j.compedu.2018.02.013

[8] Lu, J., \& Churchill, D. The effect of social interaction on learning engagement in a social networking environment. Interactive learning environments, 2014, vol. 22(4), pp. 401-417. https://doi.org/10.1080/10494820.2012.680966

[9] Buelow, J. R., Barry, T., \& Rich, L. E. Supporting learning engagement with online college students. Online Learning, 2018, vol. 22(4), pp. 313-340. https://doi.org/10.24059/ olj.v22i4.1384

[10] Ke, F., Xie, K., \& Xie, Y. Game- based learning engagement: A theory- and data- driven exploration. British Journal of Educational Technology, 2016, vol. 47(6), pp. 1183-1201. https://doi.org/10.1111/bjet.12314

[11] Halliday, S. E., Calkins, S. D., \& Leerkes, E. M. Measuring preschool learning engagement in the laboratory. Journal of experimental child psychology, 2018, 167, pp. 93-116. https://doi.org/10.1016/j.jecp.2017.10.006

[12] Chen, I. S. Computer self-efficacy, learning performance, and the mediating role of learning engagement. Computers in Human Behavior, 2017, 72, pp. 362-370. https://doi.org/10. $\underline{\text { 1016/j.chb.2017.02.059 }}$

[13] Matsui, T., Matsui, K., \& Ohnishi, R. Mechanisms underlying math self-efficacy learning of students. Journal of Vocational Behavior, 1990, vol. 37(2), pp. 225-238. https://doi.org/ 10.1016/0001-8791(90)90042-Z

[14] Alqurashi, E. Self-efficacy in online learning environments: A literature review. Contemporary Issues in Education Research, 2016, vol. 9(1), pp. 45-52. https://doi.org/10. 19030/cier.v9i1.9549

[15] Wang, Y., Peng, H., Huang, R., Hou, Y., \& Wang, J. Characteristics of distance learners: Research on relationships of learning motivation, learning strategy, self- efficacy, attribution and learning results. Open Learning: The Journal of Open, Distance and e-Learning, 2008, vol. 23(1), pp. 17-28. https://doi.org/10.1080/02680510701815277

[16] Liu, C. C., Lu, K. H., Wu, L. Y., \& Tsai, C. C. The impact of peer review on creative selfefficacy and learning performance in Web 2.0 learning activities. Journal of Educational Technology \& Society, vol. 19(2), pp. 286-297.

[17] Schunk, D. H. (1990). Goal setting and self-efficacy during self-regulated learning. Educational psychologist, 2016, vol. 25(1), pp. 71-86. https://doi.org/10.1207/s15326985ep $\underline{2501 \_6}$

[18] Demirören, M., Turan, S., \& Öztuna, D. Medical students' self-efficacy in problem-based learning and its relationship with self-regulated learning. Medical education online, 2016, vol. 21(1), pp. 30049. https://doi.org/10.3402/meo.v21.30049

[19] Shea, P., \& Bidjerano, T. Learning presence: Towards a theory of self-efficacy, selfregulation, and the development of a communities of inquiry in online and blended learning environments. Computers \& education, 2010, vol. 55(4), pp. 1721-1731. https://doi. org/10.1016/j.compedu.2010.07.017

[20] Rafiola, R., Setyosari, P., Radjah, C., \& Ramli, M. The Effect of Learning Motivation, Self-Efficacy, and Blended Learning on Students' Achievement in the Industrial Revolution 4.0. International Journal of Emerging Technologies in Learning, 2020, vol. 15(8), pp. 71-82. https://doi.org/10.3991/ijet.v15i08.12525

[21] Schiefele, U. Interest, learning, and motivation. Educational psychologist, 1991, vol. 26 (34), pp. 299-323. https://doi.org/10.1080/00461520.1991.9653136 
[22] Harlen, W., \& Deakin Crick, R. Testing and motivation for learning. Assessment in Education: principles, policy \& practice, 2003, vol. 10(2), pp. 169-207. https://doi.org/10. $\underline{1080 / 0969594032000121270}$

[23] Lin, M. H., \& Chen, H. G. A study of the effects of digital learning on learning motivation and learning outcome. Eurasia Journal of Mathematics, Science and Technology Education, 2017, vol. 13(7), pp. 3553-3564.

[24] Liu, O. L., Bridgeman, B., \& Adler, R. M. Measuring learning outcomes in higher education: Motivation matters. Educational Researcher, 2012, vol. 41(9), pp. 352-362. https://doi.org/10.3102/0013189x12459679

[25] Liu, T. Y., \& Chu, Y. L. Using ubiquitous games in an English listening and speaking course: Impact on learning outcomes and motivation. Computers \& Education, 2010, vol. 55(2), pp. 630-643. https://doi.org/10.1016/j.compedu.2010.02.023

[26] Tella, A. The impact of motivation on student's academic achievement and learning outcomes in mathematics among secondary school students in Nigeria. Eurasia Journal of Mathematics, Science and Technology Education, 2007, vol. 3(2), pp. 149-156. https://doi.org/10.12973/ejmste/75390

[27] Rahardjanto, A., Husamah, \& Fauzi, A. Hybrid-PjBL: Learning Outcomes, Creative Thinking Skills, and Learning Motivation of Preservice Teacher. International Journal of Instruction, 2019, vol. 12(2), pp. 179-192. https://doi.org/10.29333/iji.2019.12212a

[28] Firmstone, V. R., Elley, K. M., Skrybant, M. T., Fry- Smith, A., Bayliss, S., \& Torgerson, C. J. Systematic review of the effectiveness of continuing dental professional development on learning, behavior, or patient outcomes. Journal of dental education, 2013, vol. 77(3), pp. 300-315. https://doi.org/10.1002/j.0022-0337.2013.77.3.tb05471.x

[29] Magdalena, S. M. The relationship of learning styles, learning behaviour and learning outcomes at the romanian students. Procedia-Social and Behavioral Sciences, 2015, 180, pp. 1667-1672. https://doi.org/10.1016/j.sbspro.2015.05.062

[30] Young, M. R., Klemz, B. R., \& Murphy, J. W. Enhancing learning outcomes: The effects of instructional technology, learning styles, instructional methods, and student behavior. Journal of Marketing Education, 2003, vol. 25(2), pp. 130-142. https://doi.org/10.1177/ $\underline{0273475303254004}$

[31] Henderson, D., Fisher, D., \& Fraser, B. Interpersonal behavior, laboratory learning environments, and student outcomes in senior biology classes. Journal of Research in Science Teaching: The Official Journal of the National Association for Research in Science Teaching, 2000, vol. 37(1), pp. 26-43. https://doi.org/10.1002/(sici)1098-2736(200001)37:1\% 3C26::aid-tea3\%3E3.0.co;2-i

[32] Lu, H., Jia, L., Gong, S. H., \& Clark, B. The relationship of Kolb learning styles, online learning behaviors and learning outcomes. Journal of Educational Technology \& Society, 2007, vol. 10(4), pp. 187-196.

[33] Pi, Z., Tang, M., \& Yang, J. Seeing others' messages on the screen during video lectures hinders transfer of learning. Interactive Learning Environments, 2020, pp. 1-14. https://doi.org/10.1080/10494820.2020.1749671

[34] Liu, G. F., Li, L. L., Xu, H. M., \& Luo, M. Q. Research on the Influence of Online Video Bullet-screen Advertising Marketing on Consumers' Purchasing Intention. Education and Humanities Research, 2019, 336, pp. 790-795. https://doi.org/10.2991/icsshe-19.2019.193

[35] Wan, A., Moscowitz, L., \& Wu, L. Online social viewing: Cross-cultural adoption and uses of bullet-screen videos. Journal of International and Intercultural Communication, 2020, vol. 13(3), pp. 197-215. https://doi.org/10.1080/17513057.2019.1610187 
[36] Scagnoli, N. I., Choo, J., \& Tian, J. Students' insights on the use of video lectures in online classes. British Journal of Educational Technology, 2019, vol. 50(1), pp. 399-414. https://doi.org/10.1111/bjet.12572

\section{Author}

Zhikai Li is a Lecturer in Puyang Vocational and Technical College, Puyang, Henan, 457000, China.

Article submitted 2021-11-01. Resubmitted 2021-12-22. Final acceptance 2021-12-22. Final version published as submitted by the author. 